\title{
Spring wheat mixtures in northern crop production: Quality characteristics
}

\author{
H. SALOVAARA ${ }^{1}$ and R. KARJALAINEN ${ }^{2}$
}

I Department of Food Chemistry and Technology

${ }^{2}$ Departments of Plant Pathology and Plant Breeding

University of Helsinki, SF-00710 Helsinki, Finland

\begin{abstract}
Mixtures of two or three spring wheat cultivars (Tähti/Kadett; Tähti/Kadett/ Tapio) were grown on experimental plots and the resulting crops were analyzed by selected procedures to indicate breadmaking quality. The quality tests included tests on the protein content, sedimentation values and rheological properties of doughs. Comparisons between mixtures and the means of pure components did not show any definite variations in terms of major quality characteristics. The quality of mixtures appears to be predictable from the performance of the pure components. The present study suggests that mixtures give equal quality compared with pure stands.
\end{abstract}

Index words: spring wheat, cultivar mixtures, breadmaking quality.

\section{Introduction}

The yield and quality of a wheat crop are both governed by genetic and environmental factors. In a hard climatic region used for wheat production, such as Finland, yearly fluctuations in the quantity and quality of the crop are a major problem. Genotype-environment interactions are strongly involved in these variations. Therefore, there is a hypothesis that the use of mixtures of cultivars might help in stabilizing the crop in terms of yield, disease resistance, or end-use properties. Available data (Marshall and Brown 1973,
WOLFE 1985) suggest that cultivar mixtures can improve yield stability by reducing the genotype-environment interaction and by improving crop resistance to plant pathogens. However, very little attention has been paid to the assessment of whether mixtures can affect crop quality.

In the present study we have grown mixtures of two or three spring wheat cultivars over two years in small scale field trials in order to obtain an idea of the potential of mixed cropping with respect to wheat quality. The purpose of the study was to record wheth- 
er the quality characteristics of wheat cultivated in mixtures are different from those grown separately.

\section{Materials and methods}

The data presented in this study are based on field trials carried out at the experimental farm of the University of Helsinki (Viikki) in the years 1984 and 1985 . Our test cultivars included two comparatively new high yielding cultivars, Kadett and Tapio, and an older, poor yielding and disease susceptible cultivar, Tähti, which in turn is characterized by a high protein content and good gluten quality (Mustonen et al. 1986, SalovaAra 1986).

The field experiment was laid out in a randomized block design with three replications in 1984 and four replications in 1985. Plot size was $10 \mathrm{~m}^{2}$, and $80 \mathrm{~kg} \mathrm{~N}$ levels per hectare were used. Observations of the growing wheats were made and no major disease infection was detected. Two component 50/50 mixtures involving Tähti and Kadett were used in 1984 and 1985. In the latter year three components Tähti, Tapio and Kadett, were also grown in equal amounts.

Harvested wheat samples were dried to 13$14 \%$ moisture. Hectolitre weight, 1000 kernel weight and the falling number of the samples were determined according to standard procedures applied in Finland (ANON 1979). Results of these measurements and the yields obtained are given on a $15 \%$ moisture basis.

Subsamples of $200 \mathrm{~g}$ were separated and milled to about $67-70 \%$ extraction on the Brabender Junior laboratory mill. This mill produces flours with ash contents of about $0.6-0.7 \%(\mathrm{dm})$. The flour samples were used in sedimentation tests and mixograph measurements.

Protein content of the samples was determined by the near infra-red reflectance (NIR) procedure (ANON 1983) using an Inframatic 8100 apparatus (PerCon Prufgeräte $\mathrm{GmbH}$, Hamburg, FRG). Sedimentation values were determined by the standard procedure (ANON 1978). SDS-sedimentation volumes were determined using the procedure described by AXFord et al. (1979).

Water absorption capacities of the flour samples were measured using a centrifuge method described by SosulSKI (1962). He reported on a high correlation between centrifuge absorption and farinograph absorption. In the present study, absorption recorded in the centrifuge test was used in mixograph measurements. In the present study we have assumed that mixogram determinations made with adjusted water additions would provide more information on rheological properties of dough than mixograms made with a constant water addition. Mixograms were determined by a standard procedure (ANON 1983) using a $10 \mathrm{mg}$ mixer.

All analytical measurements were made in duplicate using samples from two replicative treatments. Means of the four individual measurements are given in the tables.

\section{Results and discussion}

The data reported in this study suggest (Table 1) that most of the agronomical char-

Table 1. Quality characteristics of wheats cultivated in combinations and separately.

\begin{tabular}{|c|c|c|c|c|c|c|c|c|c|c|c|c|c|}
\hline \multirow{3}{*}{$\begin{array}{l}\text { Quality } \\
\text { characteristics } \\
\text { of grains }\end{array}$} & \multicolumn{4}{|c|}{ Experiment A 1 (1984) } & \multicolumn{4}{|c|}{ Experiment A 2 (1985) } & \multicolumn{5}{|c|}{ Experiment B (1985) } \\
\hline & \multirow{2}{*}{\multicolumn{2}{|c|}{$\begin{array}{c}\text { Tähti Kadett } \\
100 \% 100 \%\end{array}$}} & \multicolumn{2}{|c|}{$\begin{array}{l}\text { Mixture } \\
50 / 50\end{array}$} & \multirow[t]{2}{*}{$\begin{array}{l}\text { Tăhti } \\
100 \%\end{array}$} & \multirow[t]{2}{*}{$\begin{array}{l}\text { Kadett } \\
100 \%\end{array}$} & \multicolumn{2}{|c|}{$\begin{array}{c}\text { Mixture } \\
50 / 50\end{array}$} & \multirow[t]{2}{*}{$\begin{array}{l}\text { Tăhti } \\
100 \%\end{array}$} & \multirow{2}{*}{\multicolumn{2}{|c|}{$\begin{array}{l}\text { Kadett Tapio } \\
100 \% 100 \%\end{array}$}} & \multicolumn{2}{|c|}{$\begin{array}{c}\text { Mixture } \\
33 / 33 / 33\end{array}$} \\
\hline & & & exp. & obs. & & & exp. & obs. & & & & exp. & obs. \\
\hline Yield $\mathrm{kg} / \mathrm{ha}$ & 4980 & 6630 & 5805 & 5690 & 2820 & 3617 & 3219 & 3207 & 2872 & 3668 & 3257 & 3266 & 3423 \\
\hline 1000 k.weight g & 39.7 & 41.7 & 40.7 & 38.9 & 33.7 & 38.5 & 36.1 & 37.7 & 36.4 & 39.4 & 39.6 & 38.5 & 37.6 \\
\hline Hectolitre wt kg & - & - & - & - & 78.1 & 76.9 & 77.5 & 77.5 & 78.5 & 77.5 & 76.8 & 77.6 & 78.1 \\
\hline Falling number s & 282 & 197 & 240 & 214 & 404 & 279 & 342 & 391 & 304 & 275 & 255 & 278 & 250 \\
\hline
\end{tabular}




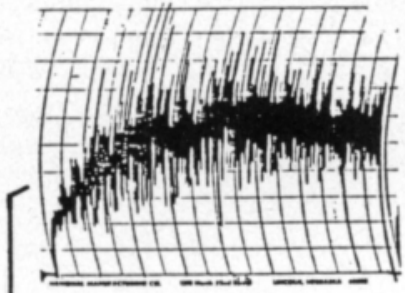

KADETT (KT)

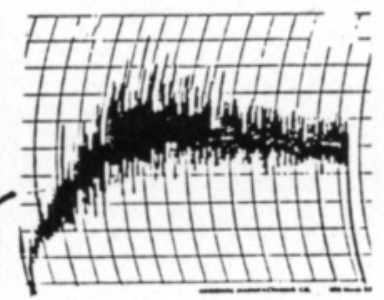

Tæ̈HTI (TI)

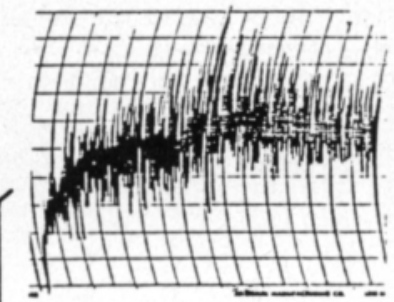

KADETT $(K T)$

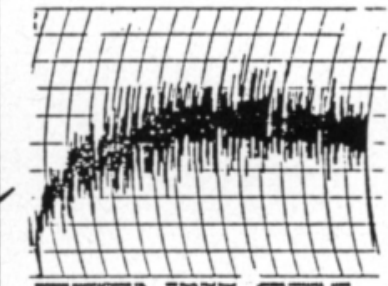

TÄHTI (TI)

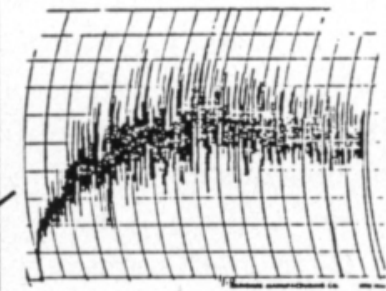

TAPIO (TO)

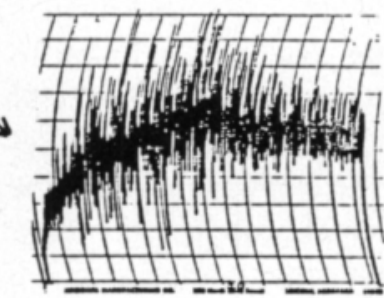

MIXTURE (KT + TI + TO)

Fig. 1. Mixograms of spring wheat cultivars and their two and three component mixtures. Components in equal amounts.

acteristics in mixtures appear to be close to the mean values of their pure components. In both series of experiments Kadett was most and Tähti least productive. Statistically no characteristics of the mixtures differed significantly from the means of their pure components. Thus, the data from Table 1 do not suggest any definite synergistic improvements in yield or quality of mixtures as related to the means of their pure components.

Table 2 shows the inherent quality characteristics of the samples from various treatments. In accordance with the data shown in Table 1, the quality of mixtures appears to be 
Table 2. Inherent quality characteristics of wheat and flours from grains cultivated in combinations and separately.

\begin{tabular}{|c|c|c|c|c|c|c|c|c|c|c|c|c|c|}
\hline \multirow{3}{*}{$\begin{array}{l}\text { Quality } \\
\text { characteristics }\end{array}$} & \multicolumn{4}{|c|}{ Experiment A 1 (1984) } & \multicolumn{4}{|c|}{ Experiment A 2 (1985) } & \multicolumn{5}{|c|}{ Experiment B (1985) } \\
\hline & \multirow{2}{*}{\multicolumn{2}{|c|}{$\begin{array}{l}\text { Tăhti Kadett } \\
100 \% 100 \%\end{array}$}} & \multicolumn{2}{|c|}{$\begin{array}{c}\text { Mixture } \\
50 / 50\end{array}$} & \multirow{2}{*}{\multicolumn{2}{|c|}{$\begin{array}{l}\text { Tähti Kadett } \\
100 \% 100 \%\end{array}$}} & \multicolumn{2}{|c|}{$\begin{array}{c}\text { Mixture } \\
50 / 50\end{array}$} & \multirow[t]{2}{*}{$\begin{array}{l}\text { Tähti } \\
100 \%\end{array}$} & \multirow{2}{*}{\multicolumn{2}{|c|}{$\begin{array}{l}\text { Kadett Tapio } \\
100 \% 100 \%\end{array}$}} & \multicolumn{2}{|c|}{$\begin{array}{c}\text { Mixture } \\
33 / 33 / 33\end{array}$} \\
\hline & & & exp. & obs. & & & exp. & obs. & & & & exp. & obs. \\
\hline Seed protein $\%$ & 13.6 & 12.4 & 13.0 & 13.1 & 12.7 & 12.2 & 12.5 & 12.5 & 13.3 & 12.7 & 13.3 & 13.1 & 13.2 \\
\hline Sedim. value $\mathrm{ml}$ & 33 & 41 & 37 & 30 & 41 & 44 & 43 & 37 & 43 & 43 & 33 & 40 & 36 \\
\hline SDS-sedim value $\mathrm{ml}$ & 59 & 73 & 66 & 68 & 77 & 85 & 81 & 84 & 74 & 85 & 76 & 78 & 79 \\
\hline $\begin{array}{l}\text { Centrifuge } \\
\text { absorption } \%\end{array}$ & 61.8 & 57.0 & 59.4 & 60.0 & 63.5 & 59.2 & 61.4 & 61.2 & 63.8 & 59.6 & 60.5 & 61.3 & 60.6 \\
\hline \multicolumn{14}{|l|}{$\begin{array}{l}\text { Mixograph } \\
\text { characteristics }\end{array}$} \\
\hline Area u. curve $\mathrm{cm} / \mathrm{cm}$ & 2151 & 152 & 152 & 164 & 121 & 133 & 127 & 163 & 136 & 109 & 142 & 129 & 134 \\
\hline Peak time min & 3.0 & 4.0 & 3.5 & 3.5 & 5.0 & 4.5 & 4.8 & 4.0 & 4.5 & 4.5 & 4.0 & 4.3 & 4.0 \\
\hline Peak height mm & 59 & 58 & 59 & 65 & 55 & 61 & 58 & 60 & 57 & 62 & 59 & 59 & 63 \\
\hline Curve ht at $7 \mathrm{~min}$ & 52 & 55 & 54 & 59 & 52 & 56 & 54 & 57 & 54 & 59 & 54 & 56 & 59 \\
\hline
\end{tabular}

in a range that could be anticipated from simple arithmetical calculations, which are confirmed by mixograms of pure stands and their mixtures (Fig. 1). Thus we did not find evidence of any definite quality improvement in mixtures compared with the means of the pure components. These observations support recent data by SAMmons and BAENZIGer (1985), who also reported that cultivar mixtures of winter wheat had no effect on the milling and baking quality in relation to pure stands. Furthermore, Wolfe et al. (1981) reported that the grain quality of barley mixtures differs little from the mean of the components in terms of protein content and malt extract. Consequently, it appears that prediction of the grain quality of mixtures on the basis of pure components is simpler than that of disease resistance or performance of yield.

The present study was carried out in circumstances where experimental plots were not affected by wheat diseases. However, our recent studies (Karjalainen and Salovaara 1986) suggest that Septoria nodorum can affect wheat quality. As it is well-known (WoLfE 1985 ) that growing mixtures is beneficial particularly under disease stress conditions, more attention should be paid to studying whether cultivar mixtures could also improve the quality of wheat under disease stress compared to pure stands.

Acknowledgements. The technical assistance of Miss Taina Kuisma and Mr. Petri Jokinen in the analytical measurements is appreciated.

\section{References}

Anon, 1983. Approved methods of the AACC. 8th ed., Methods 39-10 and 54-40. American Association of Cereal Chemists, Inc. St. Paul, Minn., USA.

ANoN, 1978. Standard methods of the ICC. International Association for Cereal Chemistry. Vienna. Verlag Moritz Schäfer, Detmold, FRG.

ANON, 1979. Viljakauppaopas. Viljantutkimustoimikunta. Helsinki.

Axford, D.W.E., Macdermott, E.E. \& Redman, D.G. 1979. Note on the sodium dodecyl sulfate test of breadmaking quality: comparison with Pelshenke and Zeleny tests. Cereal Chem. 56: 582-584.

Karjalainen, R. \& SalovaAra, H. 1986. Effect of severe infection with Septoria nodorum on spring wheat quality. (Manuscript 1986).

Marshall, D.R. \& Brown, A.D.H. 1973. Stability of performance of mixtures and multilines. Euphytica 22: $405-412$.

Mustonen, L., Pulli, S. Rantanen, O. \& Mattila, L. 1986. Virallisten lajikekokeiden tuloksia 1978-1985. 
Maatalouden tutkimuskeskus, Tiedote 5/86, Jokioinen, Finland.

SalovaArA, H. 1986. Wheat and flour quality related to baking performance in industrial French bread processes. Acta Agric. Scand. 36: 387-398.

Sammons, D.J. \& Baenziger, P.S. 1985. Performance of four winter wheat cultivars in blended populations. Field Crops Research 10: 135-142.

Sosulskı, F.W. 1962. The centrifuge method for determining flour absorption in hard red spring wheats. Cereal Chem. 39: 344-350.

\section{SELOSTUS}

\section{Lajikeseosten viljelyarvo kevätvehnän tuotannossa: Laatuominaisuudet}

\section{Hannu Salovaara}

Helsingin yliopiston elintarvikekemian ja -teknologian laitos $00710 \mathrm{Helsinki}$

\section{Reijo Karjalainen}

Helsingin yliopiston kasvipatologian ja kasvinjalostustieteen laitokset, $00710 \mathrm{Helsinki}$

Helsingin yliopiston koetilalla tutkittiin vuosina 1984 ja 1985 kevătvehnän seosviljelyn vaikutusta vehnän laatuominaisuuksiin. Tutkimuksen tavoitteena oli selvittảă seosviljelyn mahdollisuuksia parantaa hyvälaatuisen leipåvehnăn tuotantoa. Koelajikkeiksi valittiin kasvuajaltaan myőhăiset Tăhti, Hankkijan Tapio ja Kadett. Tăhti valittiin korkean valkuaispitoisuutensa ja hyvien sakolukuominaisuuksiensa perusteella, kun taas Hankkijan Tapio ja Kadett edustavat uutta satoisaa mutta laadultaan hieman heikompaa lajiketta. Koeaineistosta tehtiin tärkeimmăt laatumääritykset Helsingin yliopiston elintarvikekemian ja -teknologian laitoksella.

Tulokset osoittavat, ettă seosten sadontuotanto oli lä-
WOLFE, M.S. 1985. The current status and prospects of multiline cultivars and variety mixtures for disease resistance. Ann. Rev. Phytopathol. 23: 251-273.

Wolfe, M.S., Barret, J. \& Jenkins, J.E. 1981. The use of cultivar mixtures for disease control. In: mStrategies for the Control of Cereal Disease». (Eds. J.F. Jenkyn \& R.T. Plumb), pp. 73-80. Oxford, Blackwells.

Ms received February 13, 1987 hellä niiden komponenttien keskiarvoa. Kadett oli satoisin, kun taas Tähti oli kaikissa kokeissa selvästi heikkosatoisin. Tähden ja Kadettin seokset olivat heikkotasoisempia kuin Tähden, Tapion ja Kadettin seokset. Seosten laatuominaisuudet eivăt poikenneet olennaisesti seosten komponenttien keskiarvosta.

Valkuaispitoisuus ja valkuaisten laatu olivat seoksissa yleensă văhintäăn lajikkeiden keskiarvojen tasoa, usein hieman näitä parempia. Jauhon reologiset ominaisuudet olivat samansuuntaiset kuin valkuaisenkin. Tulokset viittaavatkin siihen, ettă vehnăn laatu ei heikkene seoksessa, mikăli viljaerien sakoluvut ovat hyviä. 